\title{
FROM THE CENTRE TO THE PERIPHERY: CZECH RECEPTION OF HERMAN HEIJERMANS' DRAMATIC WORKS IN A CULTURAL-HISTORICAL PERSPECTIVE
}

\author{
LUCIE SEDLÁČKOVÁ
}

\begin{abstract}
The article deals with the Czech reception of Herman Heijermans' dramatic works. The aim is to give a survey of the translations and productions of Heijermans' plays and to look into the aspects influencing the choice of the plays by Czech theatre companies. Four plays by Heijermans have been translated into Czech, and all of them were shown on stage repeatedly. The article provides an overview of the productions in chronological order and describes their reception in the Czech lands. It examines the extent to which the plays were chosen for esthetic, social or ideological reasons, both in the first and the latter half of the twentieth century, while taking into account the changing cultural and political circumstances.
\end{abstract}

Keywords: Herman Heijermans; Dutch theatre; Czech theatre; translation; reception; cultural transfer

\section{Introduction}

In the Czech lands, Herman Heijermans (1864-1924) became the most translated and staged Dutch playwright. Nevertheless, only four of his numerous plays have been translated into Czech (Sedláčková 2018, 168-171). Although Heijermans' contemporaries, such as Henrik Ibsen, August Strindberg or Gerhart Hauptmann, have enjoyed a great reputation with the Czech audience, it has been rather wishful thinking in Heijermans' case. The aim of this article is to map the Czech translations and productions of Heijermans' plays and to survey the aspects that influenced the choice of Heijermans' dramatic works by Czech theatre companies. The article will explore when the plays were staged and by what kind of companies, and what reactions there were to the productions. It will not concentrate on the texts themselves, but rather on the actual productions. The main research question is: what characterized the reception of Heijermans' plays in Czech productions throughout the twentieth century? And more specifically: to what extent were the plays chosen for the Czech repertoire for esthetic, social or ideological reasons?

It is important to take into account that the reception took place under different regimes: first during the time of the Habsburg monarchy (until 1918), then the democratic Republic of Czechoslovakia (1918-1938), and at last, during the communist regime 
(1948-1989). ${ }^{1}$ The main part of this article will be dedicated to the development in the first decades of the twentieth century when Heijermans' plays were translated and staged quite regularly. In that period, Dutch literature was translated into Czech in notable quantity: the translations included, in particular, Flemish and Dutch regional novels, fiction on social issues, and Dutch popular exotic and adventure novels (Engelbrecht et al. 504-508). This was, in part, thanks to the Catholic publishers, who focused in the period of the fin de siècle on social works by Hendrik Conscience and other Flemish authors, and thanks to the first literary translators (e.g. Lída Faltová, Rudolf Jordán Vonka), who started to specialize in translation from Dutch to Czech in the interwar period. That is why certain Dutch and Flemish fiction authors and genres were translated into Czech quite systematically and they apparently found a stable readership, which can be proved by a large number of reprints.

However, Dutch and Flemish drama was never translated into Czech systematically, and there was never a Dutch-Czech translator who would specialize in plays (although the established translators Lída Faltová, Ella Kazdová and Olga Krijtová translated about ten plays between the 1940s and 1980s) (Sedlácková 2018, 175-179). This is even more striking as the Czechs have been fervent theatregoers for the past centuries, a nation whose cultural emancipation often took place in the theatre world. It can probably be related to the small number of modern Dutch and Flemish playwrights who have been canonized or who have broken through on an international level; in fact, only Heijermans and the Flemish Hugo Claus got a permanent position in the literary canon, and only their works became (for a certain period) an export article from the Low Countries. Four plays by each of them got translated into Czech, but only those by Heijermans were staged regularly, especially in the first half of the twentieth century (Sedláčková 2018, 167-170).

All of the Czech translations of the four plays by Heijermans (Ahasverus, Op hoop van zegen, Allerzielen, Ghetto) were preceded by a translation into German. This is not surprising as much research has shown that the circulation of Heijermans' dramatic works in Central Europe (e.g. also in Poland and Hungary) was influenced, to a significant extent, by his enormous success and popularity in the German-speaking countries; and the preferences of German translators and theatres often had direct influence on the choices made in the other Central-European countries (Neubauer 18).

\section{Ahasverus}

The available sources show that Ahasverus (1893) was the first of Heijermans' dramatic texts to be translated into Czech. The German translation followed soon after it had come out in the Netherlands, namely in 1894 in Das Magazin für die Litteratur des In- und Auslandes, and it was rendered by the prominent mediator of Dutch literature, Paul Raché. The translation also came out in book form at the beginning of the twentieth century. Grave (66-67) remarks that Raché created significant publicity for Heijermans in Germany, not only for Ahasverus, but also for the other works that were translated or

1 There were no productions of Heijermans' plays during WWII and after 1989. 
reviewed later in the press by him. Raché argued that Heijermans' talent was all the more admirable considering the fact theatre was of marginal importance in the Netherlands.

We can find a similar, not very flattering comment accompanying the first translation of Heijermans' dramatic work in the Czech language. In 1898, the Czech translation of Ahasverus, by Jaroslav Leyder, appeared. ${ }^{2}$ This one-act-play was printed in the literary section of Kalendár̆ česko-židovský (The Czech-Jewish Almanac), which was published annually between 1881 and 1939 by the Association of Czech Academic Jews. ${ }^{3}$ In the introductory footnote, Heijermans' importance for the modern Dutch literature is emphasized (he is mentioned together with Louis Couperus, Frederik van Eeden etc.), and it is stressed that it is probably for the first time that a Dutch author has dealt with a theme situated in the Slavic area. On the other hand, the footnote ends with a bitter remark saying that Heijermans will, hopefully, become a rightful representative of the Dutch drama, which has, “apart from Constant's Lotos (by Mrs. Snijder-Wissenkerke [sic]) and the plays by Nouhuys [sic], produced nothing noteworthy". 4 This shows, among other things, that the Czech cultural mediators (editors, translators, theatre agents) kept an eye on the development abroad: the Czech theatre journal Česká Thalia: Listy pro dramatickou literaturu a umění (Czech Thalia: Journal for Dramatic Literature and Art) informed even in September 1892 in a short report about the play Lotos by the young (only 28-year-old at that time) author Marie Snijder van Wissenkerke, which received a very positive response in the Netherlands. In the same issue, Willem Gerard van Nouhuys (namely the production of his play The Goldfish in the Independent Theatre in London) was mentioned. As late as 1900 , the reviewer O. F. ${ }^{5}$ complained in a critique regarding the out-of-date repertoire of the National Theatre in Prague that there were always the same old playwrights chosen for the programme, and not any new names, such as Van Nouhuys and Heijermans (among others).

Ahasverus was the first play by Heijermans which was staged in a Czech version. The translation by Leyder (Kamper) was used twice in 1901 by Czech-Jewish amateur groups. Different periodicals, among others Divadelní listy (The Theatre Journal) on 5th May 1901, mentioned the production of Ahasverus by the Czech-Jewish youth association ${ }^{6}$ from the East-Bohemian town of Chrudim where a significant Jewish minority lived in those days. Thus, it can also be considered the very first Czech production of Heijermans' work ${ }^{7}$. Another production followed in the same year: in October, it was staged in Královské Vinohrady (at that time the fourth biggest Czech town, later annexed by Prague), namely by the dramatic section of the Prague Czech-Jewish youth association. ${ }^{8}$

This means Heijermans' work was staged for the first time by Czech amateurs who, furthermore, belonged to a religious minority. This one-act-play has an interesting history itself, because Heijermans had used it for a mystification when he presented it as a play translated from Russian (written by a certain Ivan Jelakowitch) in order to prove

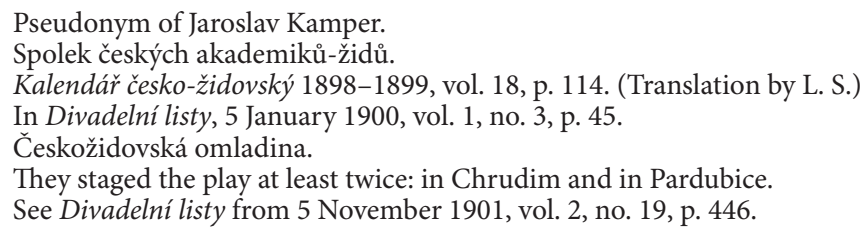


that a play written by a Russian or foreign author was accepted better than a play by a Dutch writer.

It is clear that the Jewish theme was the motivation to stage the play in Chrudim and in Vinohrady. In the fin-de-siècle period, there were diverse interest groups within the Jewish minority in the Czech territory. On the one side, there were supporters of the assimilation of the Jews within the Czech, or German culture; on the other side, the Zionists stressed their ethnic and cultural independence. The supporters of the Czech-Jewish movement did their best to integrate culturally and they published their own periodicals: at first, the above mentioned Kalendár česko-židovský, and later also Českožidovské listy (The Czech-Jewish Journal, 1894-1907). The translation and productions of Ahasverus were definitely a part of the activities supporting the use of the Czech language, but at the same time, they were a response to the anti-Semitic atmosphere in, among other lands, the Czech area. Around 1900, it was highly relevant due to the so-called Hilsner affair (1899-1901), which caused a huge wave of anti-Semitism. ${ }^{9}$

The production of Ahasverus, describing the Jewish persecution in Russia, became a small success for the Vinohrady amateurs. On the cultural evening of the Czech-Jewish youth association, Ahasverus was staged together with a Czech comedy in order to reduce the "melancholic mood of the evening", according to a review in Českožidovské listy. The journal gave this description:

[...] the suffering of the Jew, his patience and trust in God, a deep religious belief - on the other side, a weak soul, collapsed due to the suffering and under the pressure, and abandoning the faith of his forefathers - a resulting hard tragic conflict - all of this, expressed in a couple of peculiar gloomy features, made a sadly charming impression in the soul of the spectator. ${ }^{10}$

The play Ahasverus was later published once more, namely in 1905 in a translation by Oskar Fantl, but no productions of this version have been found so far.

\section{Op hoop van zegen (before 1939)}

In the case of Ahasverus, the Jewish theme was the motivation to stage the play; whereas the translation and production of Op hoop van zegen (1900, The Good Hope), which followed soon (premiere in the National Theatre in Prague in December 1901, publication in book form in 1902), were influenced by the German culture. According to a review in Divadelní listy dating from January 1902, the play had been chosen so quickly

9 The unemployed shoemaker Leopold Hilsner from the East-Bohemian village of Polná was accused of, and subsequently, sentenced for the murders of two Christian girls: the public and the judges were convinced these were ritual murders although there was no direct proof for that. It stimulated the rise of anti-Semitism. One of the critics of the lawsuit and the verdict was also the philosopher, and later president, T. G. Masaryk.

10 Českožidovské listy, 31st October 1901, vol. 7, no. 21, p. 7. (Translation by L. S.) Original version: “[...] utrpení židovského člověka, jeho trpělivost a důvěra v Boha, hluboká náboženská víra - s druhé strany slabá duše shroucená utrpením, podléhající nátlaku a odpadající od víry svých otců - z toho těžký tragický konflikt - to vše vyjádřeno v několika rázovitých, ponurých tazích zanechalo smutněkrásný dojem v duši posluchače." 
for a Czech adaptation because of its enormous success in Germany. In Germany it had been already staged in 1901 in an unauthorized translation by O. van Bergh (in May in Hamburg, in July in the Neues Theater in Berlin) and in an official translation by Franziska de Graaff-Levy (in September in the Deutsches Theater in Berlin). It was this play that led to Heijermans' breakthrough in Germany (Eenhuis 45-46). Van Uffelen (166) makes the conclusion that: "Stücke wie die Hoffnung auf Segen [...] wurden in Deutschland etwa viermal so oft wie in den Niederlanden aufgeführt, und Heijermans is wegen seines Erfolges im deutschen Sprachraum 1907 sogar nach Berlin gezogen.”

In the first decades of the twentieth century (at the time of the Habsburg monarchy and the democratic republic), the Czech version of Op hoop van zegen was staged by, at least, ten different companies. The first ones were the three most important, permanent theatres (Prague 1901, Plzeñ 1902, and Brno 1903), then it was chosen for the repertoire of the professional travelling companies and at last, it was staged mainly by small theatres and amateur groups. ${ }^{11}$

The numbers of individual performances and also some remarks in the reviews show that the Czech critics were, in general, more enthusiastic about the play than the Czech audience, which displayed little interest in the gloominess and tragic character of the play, although other naturalist or socially-inspired plays (such as those by Ibsen or Hauptmann) were quite numerous in theatre programmes. In the reviews of the productions in the permanent theatres in the first decade of the century, most of the attention is paid to acting performances. Since the play featured the best Czech actors and actresses of that time, it is not surprising that the performances were praised highly. In some reviews, the play was also compared with other plays from the repertoire of the time. Op hoop van zegen was almost always pinpointed as the best choice. ${ }^{12}$ Some reviews and reports show, however, that the productions caused a negative response in the audience, which included mainly the middle class, in the later sources indicated as the bourgeoisie.

Nevertheless, the play was, just like Allerzielen, recommended for the so-called workers' theatre. ${ }^{13}$ Those were not only companies targeting specifically such audience, but also some of the big theatres, such as the one in Plzeň, which provided cheap afternoon performances for the common people. The idea was that the folk would appreciate it better, thanks to its social message, than the middle class, which found it too depressing and pessimistic.

After a positive reception by the theatre critics in the beginning of the twentieth century, when it was praised mainly due to its dramatic effect, i.e. the esthetic quality, the play disappeared until the 1920s, when it was mentioned in the national press again. Firstly, it was recommended in the journal for workers' theatre as a play suitable for amateur groups. The synopsis had obvious features of a socialistic interpretation. The play is characterized as "powerfully dramatic and revolutionary", and most of the attention is paid to the character of Geert, who is presented as a revolutionist. ${ }^{14} \mathrm{~A}$ similar tone can be found in a review of the 1921 production by Uranie, a small theatre in the Prague periphery,

11 For more information about the productions, see Gielen \& Sedláčková 2015.

12 Divadelní listy, 5 February 1902, vol. 3, no. 5, p. 128, about the production in Plzeň; Divadelní listy, 5 November 1903, vol. 5, no. 1, p. 6, about the production in Brno.

13 Dělnické divadlo.

14 Dělnické divadlo, 1926, no. 6, p. 165. 
which was often frequented by the common folk. The review was published in Rudé právo (The Red Justice), the newspaper of the young Communist Party of Czechoslovakia, and focused only on the social aspect, commenting on the "heartless and cruel capitalism of the rich ship-owners", who are just sitting "in safety on dry land with their fortune". The main hero was, according to this review, the socialist and rebel Geert (not the female protagonist Kniertje!), since he best embodied the play's rebellious tendency. ${ }^{15}$

\section{Allerzielen}

Op hoop van zegen was translated almost immediately, whereas the Czech translation of Allerzielen (1905, All Souls) followed only a couple of years after the original. In Germany it had been translated as soon as in 1906; the Czech version was staged for the first time in 1908 and 1909 by two professional companies, namely in the Prague periphery, Smíchov, and in Brno. ${ }^{16}$ Altogether, the play has been staged by at least twenty different Czech theatre companies, except for those previously mentioned. These were almost exclusively amateur groups all over the country. Consequently, Allerzielen is the most staged Dutch play in the Czech-speaking area ever.

It was staged the most frequently between 1909 and 1924; the anticlerical intention was emphasized regularly. In this context, just like Op hoop van zegen, the play was considered suitable for socially motivated productions for labourers. The first production in Smíchov was reviewed extensively in the journal Divadlo (The Theatre); Heijermans was called a "gloomy barbarian" here and his plays were praised for their deep dramatic impact on the spectators. Heijermans, however, was not considered as a very good playwright since his texts allegedly missed a synthetic quality. According to the reviews, he was able to depict the human grief and suffering in a very impressive way, but his plays missed a literary, intellectual level: the outcome was always desperate, without an underlying idea. ${ }^{17}$

The amateur groups which staged Allerzielen in the 1910s and 1920s were often a part of workers' organizations, such as those in the East-Moravian village of Holešov (1910) and the North-Bohemian town of Liberec/Reichenberg (1914). Such groups chose for light comedy, mainly of Czech origin, or for socially engaged drama.

In the journal for workers' theatre (Dělnické divadlo) dating from January 1926, there was a recommendation to stage the play on the feast day of Saint John of Nepomuk, on the Feast of Corpus Christi, or on All Souls' Day because it would "make a stronger impression than the dry anticlerical speeches and would also hold a mirror up to the petty-bourgeois morality" (Malířová 16). This recommendation was, however, not complied with since Allerzielen was hardly ever staged again after 1925 (except for the last amateur production in 1948).

15 Rudé právo, 10 November 1921.

16 The translation was published in 1909 as: Heijermans, H. Na faře. Transl. by F. V. Krejčí. Praha: Dělnická akademie.

17 Divadlo. Rozhledy po světě divadelním, 20 December 1908, vol. 7, no. 5, p. 123. 


\section{Ghetto}

The fourth play, translated and staged in the Czech language, is Ghetto (1898). As soon as 1902, when Op hoop van zegen was on stage in the Prague National Theatre, it was mentioned in Divadelní listy. The reviewer expressed his displeasure about the fact that $O p$ hoop van zegen, not Ghetto, had been chosen: according to him, Op hoop van zegen was less original and less characteristic for the author than Ghetto, but the Czech dramaturgy had blindly copied the enormous success of Op hoop van zegen in the German-speaking area, despite the fact that Ghetto was more interesting and would have provided more inspiration for Czech playwrights. ${ }^{18}$ Again, we can see how much influence the German theatre world had on the Czech repertoire. Nevertheless, Ghetto became well-known in Germany quite quickly: it was translated in 1903 for the first time and in the 1900s it was staged in the German-speaking area (after 1905 in an adapted version, due to the pressure of Jewish critics) (Van Uffelen 175).

The Czech Jews were also familiar with the German translation of Ghetto. The Jewish journal Rozvoj (The Growth) reviewed the play in 1904, though with mixed feelings. According to the reviewer, Heijermans showed the shortcomings of both Jews and Christians, which should help reduce or eliminate the mutual, deeply rooted hatred. Still, it was not one of his best plays. "Heijermans demonstrates the bad qualities, prejudice and shortcomings without clearly indicating their source and causes." 19

Apparently, Ghetto, as opposed to Ahasverus, has not been able to appeal to the Czech Jews. The position it achieved in the Czech cultural field was really of marginal significance. Eventually, Ghetto was staged as late as in 1926 in the Jihočeské divadlo (South-Bohemian Theatre) in České Budějovice, in a translation by Stanislav Langer, the stage director. Two years later, it was staged in the same translation by the workers' theatre in the town of Kladno, well-known for its coal mines and heavy industry. The review in the journal Délnické divadlo ${ }^{20}$ was, however, limited to a short summary of the plot and comments on the acting performances.

In the 1930s, Heijermans was neither staged nor reviewed. During the Second World War, he was included in the list of prohibited playwrights in the Protektorat Böhmen und Mähren, due to his Jewish origin (Kovař́ková 270). After the war, his position moved even more to the periphery of the cultural field. He enjoyed a small revival in 1948, the beginning of a new era.

\section{Op hoop van zegen (after 1945)}

After the war, only Allerzielen and Op hoop van zegen were staged: the former only once in 1948 by amateurs, the latter three times, between 1948 and 1973. The first of the three productions was staged by a small professional theatre, namely the regional theatre in Karlovy Vary (West-Bohemia), in the autumn of 1948, less than ten months after the communist coup. The two other productions were realized by amateur groups: in 1956 by

18 Divadelní listy, 5 January 1902, vol. 3, no. 3, p. 69.

19 Rozvoj, 3 March 1904, vol. 1, no. 10, p. 4.

20 Dělnické divadlo, 1 September 1928, vol. 8, no. 9, p. 133. 
Lidové divadlo (Folk Theatre) in Kostelec nad Černými lesy, a village in Central Bohemia, and in 1973 in Karlovy Vary again, this time by the D3 company. ${ }^{21}$

Special attention must be paid to the fact that the play was staged under the communist regime, as the theatre world was controlled by severe censorship at that time, all the more in the case of western authors. It is evident that Heijermans was acceptable thanks to his socialist orientation, but it is also interesting to explore to what extent the political ideology played a role in the reception of Op hoop van zegen.

For the Czech theatre, May 1945 was even more important than the 1948 coup, as the whole system changed at that point. Before 1945, it was mostly privately-owned, but during the so-called theatre revolution in 1945, led by a number of agile communist-leaning groups inspired by the nationalization of theatres in Soviet Russia, most of the theatres were occupied by the revolutionary guards. Subsequently, measures were taken to create a system of theatres that were operated and controlled completely by the state authorities. Theatre had had a rich tradition in Bohemia and Moravia, but the societal and political function of theatre was overestimated by the communist regime and it started to be understood as a principal educational medium for the masses. Even the extraordinarily popular amateur theatre, which had been autonomous and apolitical before, was being strongly managed in an ideological way. All of the amateur groups were obliged to be included in the $\mathrm{ROH}$ (the monopolistic trade union), in the agricultural cooperatives, or in the youth associations.

As previously mentioned, Op hoop van zegen was staged by a professional company in 1948 for the last time. The small regional theatre of Karlovy Vary had a difficult position as it was obliged to fulfil the new, educational function, which included tours to distant villages, coal mines or collective farms. In order to appeal to the audience in such a small town, it was necessary to vary the repertoire frequently. In the 1948/49 season, there were 34 different productions in its repertoire, and surprisingly, Op hoop van zegen was considered the greatest success. They placed second in the national theatre competition, in the category of regional theatres. Nonetheless, the production was only reviewed in a book ${ }^{22}$ and one nation-wide newspaper, which was relatively minimal in comparison with the other plays that took part in the same competition. Erik Adolf Saudek (115-116), a prominent theatre critic and Shakespeare's translator, interpreted Op hoop van zegen perfectly in accordance with the prevailing ideology, including all the necessary clichés: the play was compared to the writings by Maxim Gorki, the poor fishermen were considered as miserable proletarians and the wealthy ship-owners as the authoritative bourgeoisie. According to Saudek, the play provided an image of an arising tendency towards socialist revolt.

However, the following case demonstrates that, even in this period, a nuanced approach was necessary. The small amateur group in Kostelec nad Černými lesy chose its plays in a very strategic way. Ideologically, they were able to identify themselves with the educational function, as we can read in their chronicle, but at the same time, they were quite ambitious in the regional amateur competitions. That is why they were planning

${ }^{21}$ In the 1948 and 1956 productions of Op hoop van zegen, the old translation by O. S. Vetti (dating from 1901) was still used; for the 1973 production, a brand new adaptation was created (via German) by Miloš Honsa, the director of the production.

22 See Saudek 1948. 
their repertoire strategically. They played mainly the Czech classics. However, when their manager discovered the old, forgotten translation of Op hoop van zegen, they did their best to appeal to the jury with this production. They had even invited the Dutch ambassador for the premiere in their village of hardly three thousand inhabitants. The jury was, however, not impressed and not even the socialist theme could initially convince them. One of the jury members stated that the play was too difficult and therefore unsuitable for an amateur group. At last, after a long discussion, the group members were able to convince the jury about the qualities of their performance and they were permitted to continue their participation in the competition. Obviously, there were also other factors involved, apart from the ideological message. The tolerance was much higher in the case of such small companies: they were free to choose lighter or traditional Czech plays (e.g. by Tyl or Jirásek) which had nothing to do with the socialist ideology.

In the "golden sixties" (term used by Just 30-31), Heijermans was not staged. A new, yet the last, production followed in 1973, in Karlovy Vary again, this time by the amateurs of the D3 company. This was in the era of the so-called normalization, the grey and dull period after the 1968 occupation of Czechoslovakia by the armies of the Warsaw Pact. After the optimistic Prague Spring, the censorship was re-introduced, but the authorities paid much less attention to theatre, which had been playing a central role in agitation so far. It became clear that theatre was not a mass medium any more, as opposed to the radio and TV. Mainly, the TV had become a real Orwellian medium at that time. In this period of principally dull theatre activities in the centres, the periphery, on the other hand, especially the amateur theatre, started to flourish. The national amateur theatre competitions became an exposition of creativity and courage, which was almost absent in the professional companies. The mutual rivalry was enormous, as well as the ambitions.

In this context, the amateur director Miloš Honsa took up the plan to create a new translation and adaptation of Op hoop van zegen for his company, by using an authorized German translation. A comparison between Honsa's adaptation and the original reveals that he tried to make the play sound even more socialistic. He made lots of changes and adjustments in the text: the character Bos, a ship-owner, is even more merciless, while other characters become even more rebellious, including old Kniertje in the adjusted closing scene. On the other hand, Honsa tried to make the play more attractive by increasing the tempo and dynamics: he omitted or shortened long passages and modernized the language. ${ }^{23}$ Altogether, the 1973 production was one of the highlights in both the company's and Honsa's career. The adaptation of Op hoop van zegen qualified for the prestigious national competition Jiráskův Hronov, where it was lucky enough to win one of the prizes, and subsequently, was reviewed in the national journal for amateur theatre. ${ }^{24}$

The production was praised especially for the acting performance of the young actor interpreting the character of Barend. ${ }^{25}$ In another review in the same issue of the journal, the production was however criticized. Those critical comments are remarkable, considering the fact that Honsa had already adjusted the play quite substantially. According to the critic, even more adjustments were needed in the weepy, sentimental scenes of such

${ }^{23}$ For more information on the translation, see Sedláčková 2015.

24 Amatérská scéna, October 1973, vol. 10. no. 10.

25 It was Ondřej Pavelka, who would later become a respected professional actor of the National Theatre in Prague. 
an old "Sozialstück". The staging should have relied more on strong dramatic conflicts; in this form, it was too static, too descriptive. ${ }^{26}$ This shows that adaptations were common, however, ideology was not the only factor. Another article from the same journal stated that the D3 group's strong point was the inventive repertoire, as they were not afraid to choose plays hardly ever staged by other ensembles. ${ }^{27}$ This comment can be for sure applied to Op hoop van zegen.

\section{Conclusion}

Dutch and Flemish drama never achieved a great success in the Czech-speaking area, compared to drama from other European cultures. That is partly due to the fact that the Low Countries did not have a great theatre production in the modern times. In the Czech lands, however, theatre was always much more popular and the domestic plays formed a considerable part of their repertoires.

It is apparent that Heijermans was primarily introduced in the Czech cultural field thanks to his success in the German-speaking countries. Especially in the first years, the progressive theatre critics praised his plays because of their esthetic qualities, but the contemporary middle-class audience could hardly identify themselves with the themes and sphere of his plays, in particular Op hoop van zegen, which was staged in the most prominent theatres. Subsequently, Heijermans' plays found their way to smaller theatres, especially workers' theatres and amateur companies, where they garnered more appreciation due to their explicit social themes. The Jewish and anticlerical motifs played a role as well, when his dramas were chosen for the different repertoires. After the Second World War, a discussion on religious (both Jewish and Christian) themes was, however, no longer desirable, and Ahasverus, Allerzielen and Ghetto were therefore not played any more. Only Op hoop van zegen was chosen, sporadically, for the repertoire of small amateur companies, and it was interpreted in accordance with the prevailing communist ideology. It is, however, not possible to claim that it was staged only thanks to its socialist engagement. The majority of the repertoires of the small and amateur theatres consisted of classical Czech plays from the nineteenth century or plays by Karel Čapek, which had nothing in common with the political propaganda and the communist ideology. Surprisingly, there were also practical factors involved when the managers and directors chose Heijermans' play again after a long time. Namely, the small theatres and the amateurs were extremely ambitious in different competitions which is why they planned their repertoire in a more strategic way. The revival of Op hoop van zegen meant a considerable risk for such small companies, but at the same time, we can see that they could also succeed in making a deep impression on the audience and the jury, if they were able to stage the play in a respectable way. ${ }^{28}$

26 Amatérská scéna, October 1973, vol. 10., no. 10, p. 5.

27 Amatérská scéna, October 1973, vol. 10., no. 10, p. 19.

28 This work was supported by the European Regional Development Fund-Project "Creativity and Adaptability as Conditions of the Success of Europe in an Interrelated World" (No. CZ.02.1.01/0.0/0. 0/16_019/0000734). 


\section{BIBLIOGRAPHY}

Amatérská scéna, October 1973.

Česká Thalia: Listy pro dramatickou literaturu a umění, 20 September 1892.

Českožidovské listy, 31 October 1901.

Dělnické divadlo, 1 September 1928.

Divadelní listy, 5 January 1900.

Divadelní listy, 5 May 1901.

Divadelní listy, 5 January 1902.

Divadelní listy, 5 February 1902.

Divadelní listy, 5 November 1903.

Divadlo. Rozhledy po světě divadelním, 20 December 1908.

Eenhuis, Stance. "'Die Fische werden schwer bezahlt.' Herman Heijermans en zijn Duitse vertaalster Franziska de Graaff-Levy, 1901-1912." Jaarboek Letterkundig Museum 4. Den Haag: Nederlands Letterkundig Museum en Documentatiecentrum, 1994. 37-60.

Engelbrecht, Wilken, et al. Dějiny nizozemské a vlámské literatury. Praha: Academia, 2015.

Gielen, Albert and Sedláčková, Lucie. "De vis werd ook in Tsjechië duur betaald. Heijermans' Op hoop van zegen in Tsjechische vertalingen, opvoeringen en besprekingen." Praagse Perspectieven 10. Ed. Ellen Krol, Jan Pekelder, and Albert Gielen. Praha: Filozofická fakulta Univerzity Karlovy, 2015. 71-88.

Grave, Jaap. Zulk vertalen is een werk van liefde. Bemiddelaars van Nederlandstalige literatuur in Duitsland 1890-1914. Nijmegen: Vantilt, 2001.

Heijermans, Herman. Ahasver. Transl. by Paul Raché. Das Magazin für die Litteratur des In- und Auslandes 30 (1894): 929-937.

Heijermans, Herman. Ahasver. Transl. by Jaroslav Leyder. Kalendář česko-židovský 18 (1898): 114-125. Online: http://www.digitalniknihovna.cz/zmp/view/uuid:aec24707-435d-11dd-b505 -00145e5790ea?page=uuid:6dfd0cc3-435e-11dd-b505-00145e5790ea

Heijermans, Herman. Ahasver. Transl. by Oskar Fantl. Unhošt: F. S. Frabša, 1905.

Heijermans, Herman. Naděje. Transl. by O. S. Vetti. Praha: F. Šimáček, 1902.

Heijermans, Herman. Na faře. Transl. by F. V. Krejčí. Praha: Dělnická akademie, 1909.

Heijermans, Herman. Ghetto. Trans. by Stanislav Langer. Praha: Thespis, [19--].

Heijermans, Herman. Lod'jménem Naděje. Transl. by Miloš Honsa. Praha: Dilia, 1973.

Just, Vladimír: Divadlo v totalitním systému. Př́běh českého divadla (1945-1989) nejen v datech a souvislostech. Praha: Academia, 2010.

Kovař́k ková, Olga. Cenzura a její vliv na divadelní život v Protektorátu Čechy a Morava. Praha: Pedagogická fakulta UK, 2013. PhD-thesis.

Malířová, Helena. "Dělnický repertoire." Dělnické divadlo 1 (1926): 16.

Neubauer, John. "Asynchrone affiniteiten en synchrone tegenstellingen." Van Eeden tot heden. Literaire dwarsverbanden tussen Midden-Europa en de Lage Landen. Ed. Kris van Heuckelom, Dieter De Bruyn, and Carl De Strycker. Gent: Academia Press, 2013. 13-42.

Rozvoj, 3 March 1904.

Rudé právo, 10 November 1921.

Saudek, E. A. “K dramaturgii.” Divadelní žatva 1948. Sborník dokumentů o novém československém divadle. Ed. Emanuel Janský. [Praha]: Umění lidu, 1948. 95-121.

Sedláčková, Lucie. "Heijermans' Op hoop van zegen in Tsjechische vertalingen." De Nederlandse literatuur internationaal. Centraal-Europese blikken op de Nederlandstalige literatuur. Ed. Jana Engelbrechtová. Olomouc: Univerzita Palackého, 2015. 125-145.

Sedláčková, Lucie. "Circulatie van Nederlandstalig toneel in Tsjechië, 1898-1989." Neerlandica Wratislaviensia 28 (2018): 165-181.

Uffelen, Herbert van. Moderne Niederländische Literatur im Deutschen Sprachraum 1830-1990. Münster: Zentrum für Niederlande-Studien. 1993. 


\section{ARCHIVES}

Databáze českého amatérského divadla. <http://www.amaterskedivadlo.cz> Last access: 11 May 2019.

"Ochotnické divadlo Kostelec nad Černými lesy”. Státní okresní archiv Kolín, box no. 847. Last access: 20 May 2015.

Lucie Sedláčková

Charles University

E-mail: lucie.sedlackova@ff.cuni.cz 